\title{
Synthesis of water-soluble first generation Janus-Type dendrimers bearing Asp oligopeptides and naproxen
}

\author{
Liang Ouyang ${ }^{\mathrm{a}, \mathrm{b}}$, Lifang Ma ${ }^{\mathrm{c}}$, Yanhua $\mathrm{Li}^{\mathrm{a}}$, Junzhu Pan ${ }^{\mathrm{a}}$ and Li Guo ${ }^{\mathrm{a} *}$ \\ ${ }^{a}$ Key Laboratory of Drug Targeting and Drug Delivery System of Education Ministry, Department of \\ Medicinal Chemistry, West China School of Pharmacy, Sichuan University, Chengdu 610041, P. R. \\ China \\ ${ }^{b}$ State Key Laboratory of Biotherapy, West China Hospital, Sichuan University, Chengdu, 610041, \\ P.R. China \\ ${ }^{c}$ School of Chemical Engineering, Sichuan University, Chengdu 610065, P. R. China \\ E-mail: klivis@163.com, rosaquoli2000@yahoo.com.cn
}

\begin{abstract}
To construct a water-soluble and bone-targeting non-steroidal anti-inflammatory dendritic drug carrier, a series of Asp oligopeptides and naproxen based poly amido-ester Janus dendrimers were synthesized using a conventional method and their water solubility was preliminary evaluated. The corresponding small dendritic linkers contain two or three drug moieties on the surface and two or three oligopeptides groups at the focal terminus. This design provided an effective entry for the synthesis of multiple drug carriers with water-soluble and bone-targeting.
\end{abstract}

Keywords: Janus dendrimers, drug carrier, water-soluble, bone-targeting, Asp oligopeptides, convergent synthesis

\section{Introduction}

The features of dendrimers such as monodisperse, highly branched macromolecules with well-defined three dimensional structures, made them have many properties that significantly differ from those of corresponding linear polymers. ${ }^{1-3}$ Due to the ability to control the synthesis, the large globular structure and functionality of dendrimers, they have been found to use in applications such as light-harvesting systems, catalysis and drug delivery. ${ }^{4-6}$

The art of designing dendritic macromolecules progresses toward the synthesis of more and more sophisticated compounds, including those with several types of terminal groups, precisely placed on different areas of the surface. Such compounds can be called "Janus" or surface-block 
codendrimers. ${ }^{7}$ The synthesis of part of these compounds have already been described, often using them for self-assembly or as liquid crystals. ${ }^{8-10}$ Frechet et. al. designed and prepared such kind of Janus dendrimer which consisted of two covalently attached dendrons for drug delivery and related therapeutic applications. ${ }^{19}$ These new carriers were useful for improving the effect of polymer on pharmacokinetic properties. ${ }^{20-21}$

Our interest in this kind of dendrimers is their biomedical applications as drug delivery vehicles. One of strong demand arising from the biomedical field is the availability of Janus-type dendritic structures that can assume two, or even more, different tasks such as targeting a particular site and transporting to this site a medicinally active drug. This demand has propelled intense research into the design of dendritic species that carry at least two different types of functional groups that probably located at their periphery and/or at their core and in the inner layers. Janus dendrimer was consisted of two covalently attached dendrons where one dendron provided multiple functional handles for the attachment of therapeutically active chains, while the other could be used for attachment of solubilizing or targeting moieties. Our previous work focused on a well-known bone-targeting and solubilizing moiety: the Asp oligopeptides ${ }^{12}$ (Asp oligopeptides are novel bone-targeting moieties with 4-6 consecutive negatively charged amino acid residues so that they can readily adsorb to certain calcium containing surfaces and exhibit a remarkable affinity to bone-hydroxyapatite ${ }^{13-15}$ ).<smiles>NC(CC(=O)OCc1ccccc1COC(=O)C(CC(=O)OCc1ccccc1)NC(=O)C(CC(=O)OCc1ccccc1)NC(=O)C(CC(=O)OCc1ccccc1)NC(=O)C(N)CC(=O)OCc1ccccc1)C(=O)NC(CC(=O)OCc1ccccc1)C(=O)NC(CC(=O)OCc1ccccc1)C(=O)NC(CC(=O)OCc1ccccc1)C(=O)NC(CC(=O)OCc1ccccc1)C(=O)OCc1ccccc1</smiles>

1a

$1 \mathbf{b}$

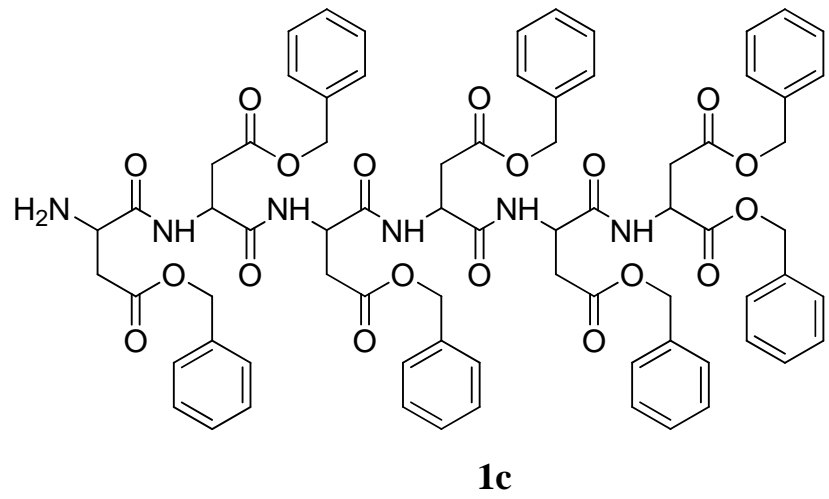

Figure 1. Structure of the fully protected Asp 4-6, 1a-c.

The peptide dendrimers bearing the oligopeptides we synthesized were found that with higher 
numbers of total oligopeptides groups attached exhibited their intended effect: faster initial binding and greater total in vitro bone targeting effect. ${ }^{11}$ As parts of our continuing efforts to this work, we aimed to build up bis-functionalized Janus-type peptide dendrimers which consisted of multiple bone-targeting polar functionalized end (Asp oligopeptides), and multiple nonpolar liposoluble model drug end (naproxen unit). We hope that this kind of dendrimers can be a satisfactory bone-targeting prodrug with increased water solubility, bone-targeting effect and good pharmacological \& pharmacokinetic characteristics.

\section{Results and Discussion}

\section{The dendrimer design}

In order to ensure a better performance of active drug release from the dendritic structures, the naproxen unit should be conjugated by a biodegradable linkage. It has been demonstrated that ester bond linkage to non-steroidal anti-inflammatory drugs (NSAIDs) does not impair its anti-inflammatory activity. ${ }^{22-23}$ However, compared with the free drug, the active of NSAID would be decreased with amide conjugates. ${ }^{16}$ On the other hand, the backbone of the dendrimer is designed as polyamide linkage with amide functionality at terminus to attach the bone-targeting oligopeptides. Therefore, the dendritic prodrugs may undergo complete disassembly to release their active free drug upon a single enzyme cleavage in vivo. ${ }^{17}$

Chemical conjugation to a dendritic scaffold, thereby exploiting the high multivalency, allows for the covalent attachment of different kinds of active molecules (imaging agents, drugs and targeting moieties) in a controlled ratio. We synthesized two series of first generation Janus dendrimer based on different cores: benzyl 3-(bis(2-hydroxyethyl)amino)propanoate and TRIS (Tris(hydroxymethyl)aminomethane). The corresponding small dendritic linkers contained two or three drug moieties on the surface and two or three oligopeptides groups at the focal terminus for bone-targeting.

\section{Synthesis}

The synthetic procedure of Janus-type dendrimers involved several iterative protection-deprotection steps of orthogonally protected building blocks. The synthetic procedure of the dimmer was outlined in Scheme 1. First, benzyl acrylate was conjugated to diethanolamine through a simple Michael addition to obtain the compound $\mathbf{3}$. The protected first generation naproxen dendritic core $\mathbf{4}$ was obtained by divergent synthesis of $\mathbf{3}$ with naproxen in the presence of EDCI.HCl (1-(3-Dimethylaminopropyl)- 3-ethylcarbodiimide Hydrochloride) and DMAP (Dimethylamino pyridine) in dichlormethane. The activation of the focal point was done by the removal of benzyl group by catalytic hydrogenolysis giving the compound $\mathbf{5}$. The dendritic peptides 6a-c were synthesized by the procedure in literatures. ${ }^{12}$ The synthesis of protected first generation codendrimers $\mathbf{L 1}$ was carried out in dichloromethane utilizing the EDCI/HOBt (N-Hydroxybenzotriazole) coupling between two dendrons $\mathbf{5}$ and 6a-c. The purification of the 
molecule was done by silica column chromatography using methanol and dichlormethane as an eluent. After removal of the protected groups with $\mathrm{H}_{2} / \mathrm{Pd}-\mathrm{C}$, the target molecules T1a-c were obtained as white powders.<smiles>C=CC(=O)OCc1cccc([C@H]2CCCCO2)c1</smiles><smiles>COc1ccc2cc(C(C(=O)OCCN(CCOC(=O)[C@H](C)c3ccc4cc(OC)ccc4c3)CCC(=O)O)c3ccc4cc(OC)ccc4c3)ccc2c1</smiles>

4<smiles>[R]OCCCN(CCC([R20])OC(C)(C)C)C(=O)CN</smiles>

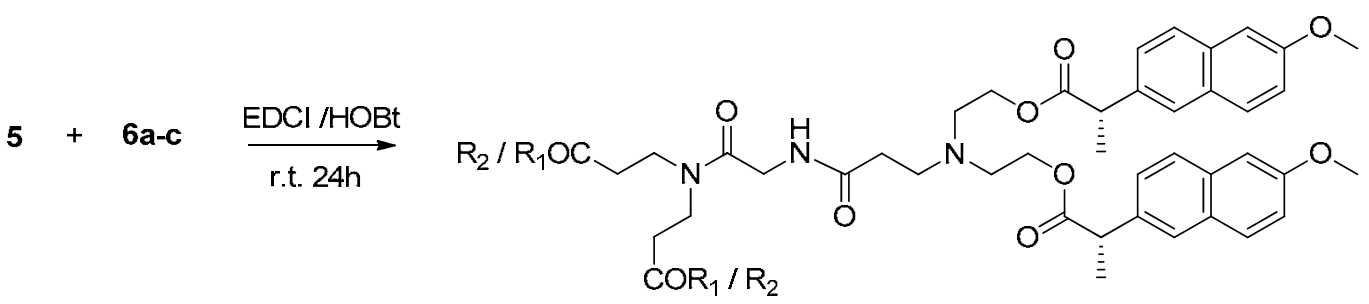

$\operatorname{L1a-c}\left(\mathbf{R}_{1}\right) \underset{\text { r.t. } 24 \mathrm{~h}}{\stackrel{\mathrm{Pd} / \mathrm{C}}{\longrightarrow}} \operatorname{T1a-c}\left(\mathbf{R}_{\mathbf{2}}\right)$

\begin{tabular}{|l|l|}
\hline $\mathrm{R}_{1}=\mathrm{NH}-(\mathrm{Asp}(\mathrm{OBzl})) \mathrm{n}-\mathrm{OBzl}$ & 6a, L1a,T1a, $\mathbf{n = 4}$ \\
& 6b, L1b,T1b, $\mathbf{n = 5}$ \\
$\mathrm{R}_{2}=\mathrm{NH}-\mathrm{Asp}(\mathrm{n})-\mathrm{OH}$ & 6c, L1c,T1c, $\mathbf{n = 6}$
\end{tabular}

Scheme 1. Preparation of the target molecules T1.

The tri-naproxen 11 was synthesized based on Cbz-TRIS and 4-(benzyloxy)-4-oxobutanoic acid in four steps with protection-deprotection. (Scheme 2) Tri-oligopeptides 12a-c were synthesized following literature precedent. ${ }^{11}$ The protected tri-dendrimers $\mathbf{L} \mathbf{1}$ were synthesized by EDCI/HOBt coupling of each building block 11 and 12a-c. (Scheme 2) The purification of the molecule was done by silica column chromatography using methanol and dichlormethane as an eluent. After removal of 
the protected groups with $\mathrm{H}_{2} / \mathrm{Pd}-\mathrm{C}$, the target molecules T2a-c were obtained as white powders.
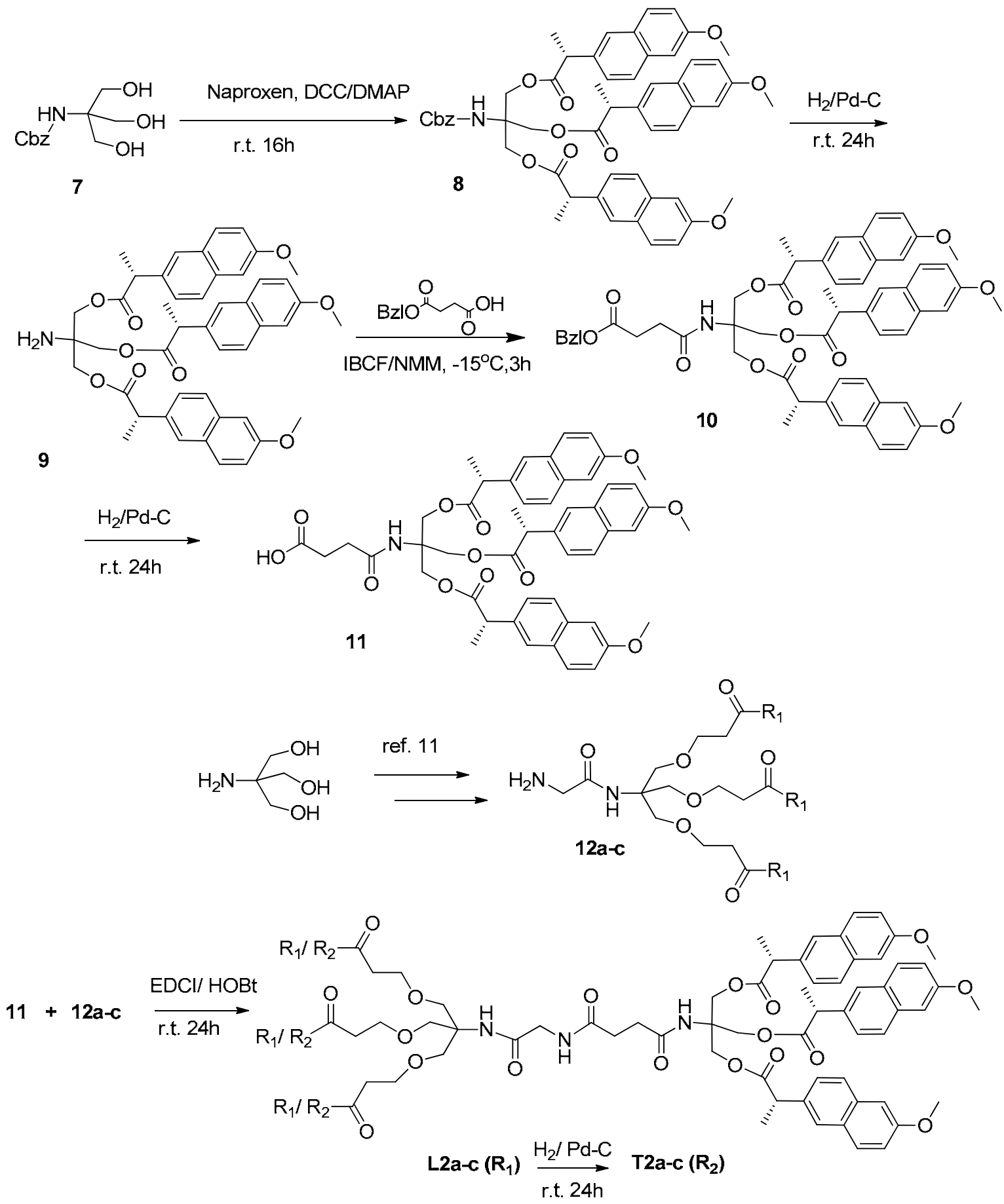

\begin{tabular}{|l|l|}
\hline $\mathrm{R}_{1}=\mathrm{NH}-(\mathrm{Asp}(\mathrm{OBzl})) \mathrm{n}-\mathrm{OBzl}$ & 12a, L2a,T2a, $\quad \mathrm{n}=\mathbf{4}$ \\
& 12b, L2b,T2b, $\quad \mathbf{n = 5}$ \\
$\mathrm{R}_{2}=\mathrm{NH}-\mathrm{Asp}(\mathrm{n})-\mathrm{OH}$ & 12c, L2c,T2c, $\quad \mathbf{n = 6}$
\end{tabular}

Scheme 2. Preparation of the target molecules T2. 
The high degree of symmetry in these dendrimers enabled facile confirmation of both structure and purity by NMR techniques. For example, in the ${ }^{1} \mathrm{H}$ NMR spectrum of dendrimer T1a-c the naproxen protons observed the resonance signals at $1.44(\mathrm{~s}), 2.36(\mathrm{t})$, and $3.53(\mathrm{t})$ ppm were clearly distinguishable from the resonances arising from the wedges (Asp oligopeptides) at $2.71(\mathrm{~m})$ and $4.84(\mathrm{~m}) \mathrm{ppm}$. Integration of the respective areas of the core protons and $\beta$-methine protons of Asp oligopeptides confirmed the complete coupling of the compound $\mathbf{5}$ and 6a-c. Furthermore, the structures of these dendrimers were further verified by ESI MS. All of the spectra displayed a very prominent peak corresponding to the dendrimers complexed with protons or sodium cation. Moreover, elemental analysis was also in good agreement with those of the target structures.

\section{Water solubility}

Since it was assumed that increasing the number of polar groups at the periphery would improve the water solubility of the prodrug, we carried out a simple water solubility test by dissolving $1 \mathrm{mg}$ Asp oligopeptides functionalized dendrimers in $1 \mathrm{ml}$ of water in a test tube. ${ }^{18}$ All the dendrimers $\mathbf{T 1}$ and T2 with several carboxy groups in periphery were all slightly dissolved in water. The naproxen and naproxen prodrugs (compound 4 and 10) with the same weight were observed nearly insoluble in water. According to the observations, the codendrimers with two or three oligopeptides were adequate to enhance water solubility and the solubility was more than $1 \mathrm{mg} / \mathrm{ml}$. It was expected that every additional generation, which doubles the number of the peripheral oligopeptides groups will improve the water solubility of the higher generation dendrimers. The improvement of water-solubility indicated the improved biocompatibility and brought the convenience of biodistribution and pharmacokinetic analysis in vivo.

\section{Conclusions}

In conclusion, we have prepared a range of first-generation monodisperse Janus dendrimer conjugates bearing two or three Asp oligopeptides sequences and naproxen molecules as the peripheral groups. T1 and T2 take advantage of a dendritic display to carry multiple drug molecules and targeting moieties. The ${ }^{1} \mathrm{H}$ NMR, MS results support the formation of the targeted dendrons and dendrimers. We are continuing exploring higher generations of dendritic molecules which bearing more Asp and drug sequences. Preliminary study of biodistribution and pharmacokinetic analysis of these conjugates will allow studying the relationship between the molar ratio of drug/targeting moieties and the potency of bone-targeting therapeutics and will be reported in due course.

\section{Experimental Section}

General. The reactions requiring anhydrous conditions were performed in an Ar or $\mathrm{N}_{2}$ atmosphere. 
The chemicals and solvents were A.R. grade and purified by standard techniques. Thin layer chromatography (TLC): silica gel plates $\mathrm{GF}_{254}$; Compounds were visualized by irradiation with UV light and/or by treatment with a solution of phosphomolybdic acid ( $20 \% \mathrm{wt}$. in ethanol) followed by heating. ${ }^{1} \mathrm{H}$ NMR analysis was performed by the INOVA VARIAN $400 \mathrm{MHz}$ spectrometer using $\mathrm{CDCl}_{3}$ or $\mathrm{D}_{2} \mathrm{O}$ as a solvent at room temperature. The chemical shifts are expressed in relative to TMS $(=0 \mathrm{ppm})$ and the coupling constants J in Hz. Elemental analysis was performed by Atlantic Microlab, Atlanta, GA, USA. ESI mass spectrum was recorded with Agilent 1946B ESI-MS instrument.

Synthesis of benzyl 3-(bis(2-hydroxyethyl)amino)propanoate (3). The compound 2 ( $0.9 \mathrm{~g} 5.5$ $\mathrm{mmol})$ and diolamine $(0.85 \mathrm{~g} 8.1 \mathrm{mmol})$ were dissolved in methanol and were stirred at room temperature overnight. After evaporated the solvent under reduced pressure, the concentrated solution was taken up in ethyl acetate $(30 \mathrm{ml})$ and washed with brine $(10 \mathrm{ml})$ three times, then dried by $\mathrm{Na}_{2} \mathrm{SO}_{4}$ and evaporated the ethyl acetate, the compound 3 was obtained as yellow oil $1.14 \mathrm{~g}$. (Yield 77.7\%) ${ }^{1} \mathrm{H}$ NMR (400 MHz, $\mathrm{CDCl}_{3}$ ): 2.54 (t, $2 \mathrm{H}, J=6.4 \mathrm{~Hz}, \mathrm{COCH}_{2}$ ), 2.63 (t, 4H, J=5.2 Hz, $\left.\mathrm{N}-\mathrm{CH}_{2} \times 2\right), 2.86\left(\mathrm{t}, 2 \mathrm{H}, J=6.4 \mathrm{~Hz}, \mathrm{~N}-\mathrm{CH}_{2}\right), 3.59\left(\mathrm{t}, 4 \mathrm{H}, J=5.2 \mathrm{~Hz}, \mathrm{CH}_{2}-\mathrm{O} \times 2\right), 5.14$ (s, $2 \mathrm{H}, \mathrm{ph}-\mathrm{CH}_{2}$ ), 7.34-7.37 (m, 5H, ph-H). ESI MS (m/z): calcd. for 267.3 obsd. $289.7\left([\mathrm{M}+\mathrm{Na}]^{+}\right)$.

Synthesis of compound (4). Compound $3(150 \mathrm{mg} 0.56 \mathrm{mmol})$ was dissolved in $\mathrm{CH}_{2} \mathrm{Cl}_{2}(15 \mathrm{ml})$, then added naproxen $(260 \mathrm{mg} 1.13 \mathrm{mmol})$ to the reaction mixture followed by DCC (N,N'-Dicyclohexylcarbodiimide) (233 mg $1.13 \mathrm{mmol})$ and DMAP (14 $\mathrm{mg} 0,113 \mathrm{mmol})$. The reaction mixture was stirred at room temperature overnight, then filtrated and evaporated under reduced pressure. The concentrated solution was taken up in ethyl acetate $(30 \mathrm{ml})$ and washed with $1 \mathrm{M} \mathrm{HCl}(10 \mathrm{ml})$, brine $(10 \mathrm{ml}), 1 \mathrm{M} \mathrm{NaHCO}_{3}(10 \mathrm{ml})$. The crude product was purified by silica gel column chromatography using PE-EA (5:1-3:1, v/v) as an eluent to obtain compound $\mathbf{4}$ as colorless oil $440 \mathrm{mg}$. (Yield 85.3\%) ${ }^{1} \mathrm{H}$ NMR (400 MHz, $\mathrm{CDCl}_{3}$ ): 1.54 (d, 6H, $J=7.2 \mathrm{~Hz}, \mathrm{NapCH}_{3} \times 2$ ), 2.30 $\left(\mathrm{t}, 2 \mathrm{H}, J=6.8 \mathrm{~Hz}, \mathrm{COCH}_{2}\right), 2.60$ (t, $\left.4 \mathrm{H}, J=6 \mathrm{~Hz}, \mathrm{~N}-\mathrm{CH}_{2} \times 2\right), 2.73\left(\mathrm{t}, 2 \mathrm{H}, J=6.8 \mathrm{~Hz}, \mathrm{~N}-\mathrm{CH}_{2}\right), 3.78$ (q, $2 \mathrm{H}, J=7.2 \mathrm{~Hz}, \mathrm{NapCOCH} \times 2$ ) $, 3.91\left(\mathrm{~s}, 6 \mathrm{H}, \mathrm{NapOCH}_{3} \times 2\right), 3.99$ (t, $\left.4 \mathrm{H}, J=6 \mathrm{~Hz}, \mathrm{CH}_{2}-\mathrm{O} \times 2\right), 5.05$ (s, 2H, ph- $\left.\mathrm{CH}_{2}\right), 7.08-7.68$ (m, 17H, Nap-phH + ph-H). ESI MS (m/z): calcd. for 691.8 obsd. 692.2 $\left([\mathrm{M}+\mathrm{H}]^{+}\right)$.

Synthesis of compound (5). A mixture of compound $4(400 \mathrm{mg})$ and $10 \% \mathrm{Pd} / \mathrm{C}(100 \mathrm{mg})$ in methanol was stirred at room temperature under a $\mathrm{H}_{2}$ atmosphere. After $24 \mathrm{~h}$ the mixture passed though a membrane filter to remove the catalyst and evaporated under reduced pressure to obtained compound 5 as colorless oil $250 \mathrm{mg}$. (Yield 91.7\%) ${ }^{1} \mathrm{H}$ NMR (400 MHz, $\left.\mathrm{CDCl}_{3}\right): 1.54(\mathrm{~d}, 6 \mathrm{H}, J=7.2$ $\left.\mathrm{Hz}, \mathrm{NapCH}_{3} \times 2\right), 2.30\left(\mathrm{t}, 2 \mathrm{H}, J=6.8 \mathrm{~Hz}, \mathrm{COCH}_{2}\right), 2.60\left(\mathrm{t}, 4 \mathrm{H}, J=6 \mathrm{~Hz}, \mathrm{~N}-\mathrm{CH}_{2} \times 2\right), 2.73(\mathrm{t}, 2 \mathrm{H}, J=$ $\left.6.8 \mathrm{~Hz}, \mathrm{~N}-\mathrm{CH}_{2}\right), 3.78$ (q, $\left.2 \mathrm{H}, J=7.2 \mathrm{~Hz}, \mathrm{NapCOCH} \times 2\right), 3.91\left(\mathrm{~s}, 6 \mathrm{H}, \mathrm{NapOCH}_{3} \times 2\right), 3.99$ (t, $4 \mathrm{H}, J=6$ $\left.\mathrm{Hz}, \mathrm{CH}_{2}-\mathrm{O} \times 2\right), 5.05$ (s, 2H, ph-CH $\left.{ }_{2}\right), 7.08-7.68$ (m, 17H, Nap-phH + ph-H). ESI MS (m/z): calcd. for 691.8 obsd. $692.2\left([\mathrm{M}+\mathrm{H}]^{+}\right)$.

\section{General procedure for the synthesis of the dendrimer $\mathrm{L} 1$}

The protected oligopeptide dendrimers 6a-c (1.0 equiv), Compound 5 (1.0 equiv) and HOBt (1.1 equiv) dissolved in anhydrous THF. EDCI.HCl (1.1 equiv) was added into the solution. The reaction mixture was stirred at room temperature for $24 \mathrm{~h}$. The solution was then concentrated under vacuum, 
and the crude product was purified by a silica gel chromatography column using $\mathrm{CH}_{2} \mathrm{Cl}_{2}$ and $\mathrm{CH}_{3} \mathrm{OH}$ $(100: 1-30: 1, \mathrm{v} / \mathrm{v})$ as an eluent.

L1a. Nankin wax (0.32 g, 75.2\%) from 5 (0.1 g, $0.17 \mathrm{mmol}) .{ }^{1} \mathrm{H}$ NMR (400 MHz, $\left.\mathrm{CDCl}_{3}\right): 1.49$ (s, $6 \mathrm{H}, \mathrm{NapCH}_{3} \times 2$ ), 2.32-2.42 (m, 6H, $\mathrm{COCH}_{2} \times 3$ ), 2.51-2.64 (brs, 6H, N-CH$\times 3$ ), 2.75-3.04 (brs, 16H, Asp- $\mathrm{CCH}_{2}$ ), 3.46-3.64 (m, 4H, $\left.\mathrm{CONCH}_{2} \times 2\right), 3.69-3.78$ (brs, $\left.2 \mathrm{H}, \mathrm{NapCOCH} \times 2\right), 3.85(\mathrm{~s}, 6 \mathrm{H}$, $\left.\mathrm{NapOCH}_{3} \times 2\right)$, 3.96-4.17 (m,6H, $\left.\mathrm{CH}_{2}-\mathrm{O} \times 2+\mathrm{Gly}-\mathrm{CH}_{2}\right), 4.56-4.98(\mathrm{~m}, 8 \mathrm{H}, \mathrm{Asp}-\alpha \mathrm{CH}), 5.03(\mathrm{~s}, 20 \mathrm{H}$, ph- $\left.\mathrm{CH}_{2}\right), 7.04-7.71(\mathrm{~m}, 62 \mathrm{H}, \mathrm{Nap}-\mathrm{phH}+\mathrm{phH})$. ESI MS (m/z): calcd. for 2623.8 obsd. 2624.5([M+H] $\left.]^{+}\right)$.

L1b. Yellow oil (0.41 g, 79.2\%) from 5 (0.1 g, $0.17 \mathrm{mmol}) .{ }^{1} \mathrm{H}$ NMR (400 MHz, $\left.\mathrm{CDCl}_{3}\right): 1.54$ (s, 6H, $\mathrm{NapCH}_{3} \times 2$ ), 2.36-2.49 (m, 6H, $\mathrm{COCH}_{2} \times 3$ ), 2.55-2.66 (brs, 6H, N-CH$\times 3$ ), 2.81-2.99 (brs, 20H, Asp- $\left.\mathrm{BCH}_{2}\right)$, 3.48-3.68 (m, 4H, $\left.\mathrm{CONCH}_{2} \times 2\right), 3.72-3.76(\mathrm{~m}, 2 \mathrm{H}, \mathrm{NapCOCH} \times 2), 3.92(\mathrm{~s}, 6 \mathrm{H}$, $\left.\mathrm{NapOCH}_{3} \times 2\right)$, 4.01-4.20 (m,6H, $\left.\mathrm{CH}_{2}-\mathrm{O} \times 2+\mathrm{Gly}_{-} \mathrm{CH}_{2}\right), 4.60-4.99(\mathrm{~m}, 10 \mathrm{H}, \mathrm{Asp}-\alpha \mathrm{CH}), 5.13(\mathrm{~s}, 24 \mathrm{H}$, ph- $\left.\mathrm{CH}_{2}\right), 7.15-7.71(\mathrm{~m}, 72 \mathrm{H}, \mathrm{Nap}-\mathrm{phH}+\mathrm{phH})$. ESI MS (m/z): calcd. for $3034.2 \mathrm{obsd}$. 1518.2([M+2H $\left.]^{+} / 2\right)$.

L1c. Yellow oil (0.48 g, 82.1\%) from 5 (0.1 g, $0.17 \mathrm{mmol}) .{ }^{1} \mathrm{H}$ NMR (400 MHz, $\left.\mathrm{CDCl}_{3}\right): 1.47$ (s, 6H, $\left.\mathrm{NapCH}_{3} \times 2\right), 2.31-2.46\left(\mathrm{~m}, 6 \mathrm{H}, \mathrm{COCH}_{2} \times 3\right), 2.58-2.64\left(\mathrm{~m}, 6 \mathrm{H}, \mathrm{N}-\mathrm{CH}_{2} \times 3\right), 2.77-2.98$ (brs, 24H, Asp- $\mathrm{BCH}_{2}$ ), 3.43-3.66 (m, 4H, $\left.\mathrm{CONCH}_{2} \times 2\right), 3.69-3.78$ (brs, $\left.2 \mathrm{H}, \mathrm{NapCOCH} \times 2\right), 3.85(\mathrm{~s}, 6 \mathrm{H}$, $\left.\mathrm{NapOCH}_{3} \times 2\right)$, 3.96-4.17 (m,6H, $\left.\mathrm{CH}_{2}-\mathrm{O} \times 2+\mathrm{Gly}_{-} \mathrm{CH}_{2}\right), 4.46-4.97$ (m, 8H, Asp- $\left.\alpha \mathrm{CH}\right), 5.11(\mathrm{~s}, 28 \mathrm{H}$, ph- $\left.\mathrm{CH}_{2}\right)$, 7.14-7.71 (m, 82H, Nap-phH + phH). ESI MS (m/z): calcd. for 3444.6 obsd. 1723.5 $\left([\mathrm{M}+2 \mathrm{H}]^{+} / 2\right)$.

\section{General Procedure for the Synthesis of the dendrimer T1}

A mixture of dendrimer $\mathbf{L 1}$ (1.0 equiv) and $10 \% \mathrm{Pd} / \mathrm{C}$ ( 0.1 equiv) in methanol was stirred at room temperature under a $\mathrm{H}_{2}$ atmosphere. After $24 \mathrm{~h}$ the mixture passed through a membrane filter to remove the catalyst, then evaporated under reduced pressure. After concentration, the residue was triturated with pure ethyl ether to afford $\mathbf{T 1}$ as white powders.

T1a. 0.12 g, $95 \%$ from L1a 0.2 g. ${ }^{1} \mathrm{H}$ NMR (400 MHz, $\left.\mathrm{D}_{2} \mathrm{O}\right): 1.58$ (s, 6H, $\left.\mathrm{NapCH}_{3} \times 2\right), 2.20-2.44(\mathrm{~m}$, $6 \mathrm{H}, \mathrm{COCH}_{2} \times 3$ ), 2.58-2.64 (m, $6 \mathrm{H}, \mathrm{N}-\mathrm{CH}_{2} \times 3$ ), 2.71-2.86 (brs, $16 \mathrm{H}, \mathrm{Asp}-\beta_{\mathrm{CH}_{2}}$ ), 3.48-3.55 (m, 4H, $\left.\mathrm{CONCH}_{2} \times 2\right), 3.69-3.71(\mathrm{~m}, 2 \mathrm{H}, \mathrm{NapCOCH} \times 2), 3.78\left(\mathrm{~s}, 6 \mathrm{H}, \mathrm{NapOCH}_{3} \times 2\right), 4.09-4.18(\mathrm{~m}, 6 \mathrm{H}$, $\left.\mathrm{CH}_{2}-\mathrm{O} \times 2+\mathrm{Gly}-\mathrm{CH}_{2}\right), 4.67-4.86(\mathrm{~m}, 8 \mathrm{H}, \mathrm{Asp}-\alpha \mathrm{CH}), 7.14-7.77$ (m, 12H, Nap-phH), ESI MS (m/z): calcd. for 1708.6 obsd. $1730.2\left([\mathrm{M}+\mathrm{Na}]^{+}\right)$. Anal. calcd. for $\mathrm{C}_{74} \mathrm{H}_{89} \mathrm{~N}_{11} \mathrm{O}_{36}: \mathrm{C}, 52.02, \mathrm{H}, 5.25$, N,9.02. found: C, 52.49, H, 4.97, N, 9.22.

T1b. 0.12 g, 91\% from L1b 0.2 g. ${ }^{1} \mathrm{H}$ NMR (400 MHz, $\left.\mathrm{D}_{2} \mathrm{O}\right): 1.53$ (s, 6H, $\left.\mathrm{NapCH}_{3} \times 2\right), 2.15-2.39$ (m, $6 \mathrm{H}, \mathrm{COCH}_{2} \times 3$ ), 2.47-2.62 (m, 6H, N-CH${ }_{2} \times 3$ ), 2.77-3.04 (brs, $\left.20 \mathrm{H}, \mathrm{Asp}-\beta_{\mathrm{CH}_{2}}\right), 3.42-3.49$ (m, $4 \mathrm{H}$, $\left.\mathrm{CONCH}_{2} \times 2\right), 3.69-3.72(\mathrm{~m}, 2 \mathrm{H}, \mathrm{NapCOCH} \times 2), 3.80\left(\mathrm{~s}, 6 \mathrm{H}, \mathrm{NapOCH}_{3} \times 2\right), 4.02-4.21(\mathrm{~m}, 6 \mathrm{H}$, $\left.\mathrm{CH}_{2}-\mathrm{O} \times 2+\mathrm{Gly}_{-} \mathrm{CH}_{2}\right), 4.71-4.93(\mathrm{~m}, 10 \mathrm{H}, \mathrm{Asp}-\alpha \mathrm{CH}), 7.05-7.72(\mathrm{~m}, 12 \mathrm{H}, \mathrm{Nap}-\mathrm{phH})$, ESI MS (m/z): calcd. for 1938.7 obsd. $1939.2\left([\mathrm{M}+\mathrm{H}]^{+}\right)$. Anal. calcd. for $\mathrm{C}_{82} \mathrm{H}_{99} \mathrm{~N}_{13} \mathrm{O}_{42}: \mathrm{C}, 50.80, \mathrm{H}, 5.15, \mathrm{~N}, 9.39$. found: C, 50.54, H, 5.63, N, 9.20.

T1c. 0.11 g, 89\% from L1c 0.2 g. ${ }^{1} \mathrm{H}$ NMR (400 MHz, $\left.\mathrm{D}_{2} \mathrm{O}\right): 1.49$ (s, 6H, $\left.\mathrm{NapCH}_{3} \times 2\right), 2.21-2.33$ (m, $6 \mathrm{H}, \mathrm{COCH}_{2} \times 3$ ), 2.52-2.67 (m, 6H, N-CH${ }_{2} \times 3$ ), 2.71-2.96 (brs, $24 \mathrm{H}, \mathrm{Asp}-\beta_{\mathrm{CH}_{2}}$ ), 3.40-3.51 (m, 4H, $\left.\mathrm{CONCH}_{2} \times 2\right), 3.70-3.72(\mathrm{~m}, 2 \mathrm{H}, \mathrm{NapCOCH} \times 2), 3.84\left(\mathrm{~s}, 6 \mathrm{H}, \mathrm{NapOCH}_{3} \times 2\right), 4.01-4.17(\mathrm{~m}, 6 \mathrm{H}$, 
$\left.\mathrm{CH}_{2}-\mathrm{O} \times 2+\mathrm{Gly}-\mathrm{CH}_{2}\right), 4.76-5.01(\mathrm{~m}, 12 \mathrm{H}, \mathrm{Asp}-\alpha \mathrm{CH}), 7.15-7.80(\mathrm{~m}, 12 \mathrm{H}, \mathrm{Nap}-\mathrm{phH})$, ESI MS (m/z): calcd. for 2168.9 obsd. $2170.3\left([\mathrm{M}+\mathrm{H}]^{+}\right)$. Anal. calcd. for $\mathrm{C}_{90} \mathrm{H}_{109} \mathrm{~N}_{15} \mathrm{O}_{48}: \mathrm{C}, 49.84, \mathrm{H}, 5.07$, $\mathrm{N}, 9.69$. found: $\mathrm{C}, 50.22, \mathrm{H}, 4.81, \mathrm{~N}, 9.32$.

Synthesis of compound (8). Compound $7(100 \mathrm{mg} 0.39 \mathrm{mmol})$ was dissolved in $\mathrm{CH}_{2} \mathrm{Cl}_{2}(15 \mathrm{ml})$, then added naproxen $(300 \mathrm{mg} 1.30 \mathrm{mmol})$ to the reaction mixture followed by DCC $(270 \mathrm{mg} 1.30$ mmol) and DMAP (20 mg 0,13 mmol). The reaction mixture was stirred at room temperature over 16 h. After filtrated and evaporated under reduced pressure, the concentrated solution was taken up in ethyl acetate $(30 \mathrm{ml})$ and washed with $1 \mathrm{M} \mathrm{HCl}(10 \mathrm{ml})$, brine $(10 \mathrm{ml}), 1 \mathrm{M} \mathrm{NaHCO}_{3}(10 \mathrm{ml})$. The crude product was purified by a silica gel chromatography column using PE-EA (5:1-3:1, v/v) as an eluent to obtain compound 8 as white solid $340 \mathrm{mg}$. (Yield 94.4\%) M.P.: $120-122{ }^{\circ} \mathrm{C} .{ }^{1} \mathrm{H}$ NMR $(400$ $\left.\mathrm{MHz}, \mathrm{CDCl}_{3}\right): 1.54\left(\mathrm{~d}, 9 \mathrm{H}, J=7.6 \mathrm{~Hz}, \mathrm{NapCH}_{3} \times 3\right), 3.70(\mathrm{q}, 3 \mathrm{H}, J=7.6 \mathrm{~Hz}, \mathrm{NapCOCH} \times 3), 3.88(\mathrm{~s}$, $\left.9 \mathrm{H}, \mathrm{NapOCH}_{3} \times 3\right), 4.26\left(\mathrm{~s}, 6 \mathrm{H}, \mathrm{TRIS}-\mathrm{CH}_{2} \times 3\right), 5.24\left(\mathrm{~s}, 2 \mathrm{H}, \mathrm{ph}-\mathrm{CH}_{2}\right), 7.04-7.64(\mathrm{~m}, 23 \mathrm{H}, \mathrm{Nap}-\mathrm{phH}$ + phH). ESI MS (m/z): calcd. for 891.9 obsd. $914.2\left([\mathrm{M}+\mathrm{Na}]^{+}\right)$.

Synthesis of compound (9). A mixture of the obtained solid compound 8 (340 mg) and 10\% $\mathrm{Pd} / \mathrm{C}$ $(100 \mathrm{mg})$ in methanol was stirred at room temperature under a $\mathrm{H}_{2}$ atmosphere. After $24 \mathrm{~h}$ the mixture passed though a membrane filter to remove the catalyst, then evaporated under reduced pressure to obtain compound 9 as white powder $280 \mathrm{mg}$. (Yield 97.1\%) M.P.:134-136 ${ }^{\circ} \mathrm{C} .{ }^{1} \mathrm{H}$ NMR $(400 \mathrm{MHz}$, $\left.\mathrm{CDCl}_{3}\right): 1.46\left(\mathrm{~d}, 9 \mathrm{H}, J=7.2 \mathrm{~Hz}, \mathrm{NapCH}_{3} \times 3\right), 3.67$ (q, 3H, $\left.J=7.2 \mathrm{~Hz}, \mathrm{NapCOCH} \times 3\right), 3.85$ (s, 9H, $\left.\mathrm{NapOCH}_{3} \times 3\right), 4.21$ (s, 6H, TRIS-CH $\left.\mathrm{CH}_{2} \times 3\right), 7.04-7.64$ (m, 18H, Nap-phH).

Synthesis of compound (10). 4-(Benzyloxy)-4-oxobutanoic acid was dissolved in THF (10 ml) and cooled in an ice-brine bath for $5 \mathrm{~min}$, then added $\operatorname{IBCF}(0.07 \mathrm{ml} 0.48 \mathrm{mmol})$ and stirred for $5 \mathrm{~min}$. Added compound $9(0.28 \mathrm{~g} 0.36 \mathrm{mmol})($ dissolved in THF)slowly to the reaction mixture. The reaction mixture was stirred for $3 \mathrm{~h}$. After evaporated under reduced pressure, the concentrated solution was taken up in ethyl acetate $(30 \mathrm{ml})$ and washed with $1 \mathrm{M} \mathrm{HCl}(10 \mathrm{ml})$, brine $(10 \mathrm{ml}), 1 \mathrm{M}$ $\mathrm{NaHCO}_{3}(10 \mathrm{ml})$ three times. The crude product was purified by silica gel column chromatography $-2: 1, \mathrm{v} / \mathrm{v}$ ) as an using PE-EA (3:1 eluent to obtain compound $\mathbf{1 0}$ as white solid $15 \mathrm{mg}$. (Yield 40.5\%) M.P.: $115-117{ }^{\circ} \mathrm{C} .{ }^{1} \mathrm{H}$ NMR $\left(400 \mathrm{MHz}, \mathrm{CDCl}_{3}\right): 1.47\left(\mathrm{~d}, 9 \mathrm{H}, J=7.6 \mathrm{~Hz}, \mathrm{NapCH}_{3} \times 3\right), 1.70-1.72(\mathrm{~m}$, $\left.2 \mathrm{H}, \mathrm{COCH}_{2}\right), 2.19-2.31\left(\mathrm{~m}, 2 \mathrm{H}, \mathrm{COCH}_{2}\right), 3.72(\mathrm{q}, 3 \mathrm{H}, J=7.6 \mathrm{~Hz}, \mathrm{NapCOCH} \times 3), 3.87$ (s, 9H, $\left.\mathrm{NapOCH}_{3} \times 3\right), 4.13\left(\mathrm{~s}, 6 \mathrm{H}, \mathrm{TRIS}-\mathrm{CH}_{2} \times 3\right), 5.04\left(\mathrm{~s}, 2 \mathrm{H}, \mathrm{ph}-\mathrm{CH}_{2}\right), 7.04-7.64(\mathrm{~m}, 23 \mathrm{H}, \mathrm{Nap}-\mathrm{phH}+$ phH). ESI MS (m/z): calcd. for 948.1 obsd. $970.2([\mathrm{M}+\mathrm{Na}]+)$.

Synthesis of compound (11). A mixture of the obtained solid compound $\mathbf{1 0}(0.15 \mathrm{~g})$ and $10 \% \mathrm{Pd} / \mathrm{C}$ $\left(50 \mathrm{mg}\right.$ ) in methanol was stirred at room temperature under a $\mathrm{H}_{2}$ atmosphere. After $24 \mathrm{~h}$ the mixture passed though a membrane filter to remove the catalyst, then evaporated under reduced pressure to obtain compound $\mathbf{1 1}$ as white powder. (Yield: $96.0 \%)$. ${ }^{1} \mathrm{H}$ NMR (400 MHz, $\left.\mathrm{CDCl}_{3}\right): 1.52$ (d, 9H, $J=$ $\left.7.6 \mathrm{~Hz}, \mathrm{NapCH}_{3} \times 3\right), 1.68-1.72\left(\mathrm{~m}, 2 \mathrm{H}, \mathrm{COCH}_{2}\right), 2.22-2.29\left(\mathrm{~m}, 2 \mathrm{H}, \mathrm{COCH}_{2}\right), 3.76$ (q, $3 \mathrm{H}, J=7.6$ $\mathrm{Hz}, \mathrm{NapCOCH} \times 3), 3.89\left(\mathrm{~s}, 9 \mathrm{H}, \mathrm{NapOCH}_{3} \times 3\right), 4.21\left(\mathrm{~s}, 6 \mathrm{H}, \mathrm{TRIS}-\mathrm{CH}_{2} \times 3\right), 7.04-7.64(\mathrm{~m}, 18 \mathrm{H}$, Nap-phH).

\section{General Procedure for the Synthesis of the dendrimer T2}

According to the same procedure of preparation T1, the target molecule $\mathrm{T} 2$ could be prepared form 11 and 12. (Two steps) 
T2a. $0.16 \mathrm{~g}$ from $110.1 \mathrm{~g}\left(55 \%\right.$ in two steps). ${ }^{1} \mathrm{H}$ NMR $\left(400 \mathrm{MHz}, \mathrm{D}_{2} \mathrm{O}\right): 1.47(\mathrm{~d}, 9 \mathrm{H}, J=6.0 \mathrm{~Hz}$, $\left.\mathrm{NapCH}_{3} \times 3\right), 1.66-1.68\left(\mathrm{~m}, 2 \mathrm{H}, \mathrm{COCH}_{2}\right), 2.14-2.21\left(\mathrm{~m}, 2 \mathrm{H}, \mathrm{COCH}_{2}\right), 2.44-2.52$ (brs, $6 \mathrm{H}$, $\mathrm{COCH}_{2} \times 3$ ), 2.76-2.94 (brs, $24 \mathrm{H}$, Asp- $\beta_{\mathrm{CH}}$ ), 3.45-3.58 (brs, $6 \mathrm{H}$, TRIS- $\mathrm{OCH}_{2} \times 3$ ), 3.81-3.87 (brs, $12 \mathrm{H}, \mathrm{NapOCH}_{3} \times 3+\mathrm{NapCOCH} \times 3$ ), 4.16-4.21 (brs, $8 \mathrm{H}$, TRIS- $\left.\mathrm{CH}_{2} \times 3+\mathrm{GlyCH}_{2}\right), 4.86-5.02(\mathrm{~m}$, $12 \mathrm{H}$, Asp- $\alpha \mathrm{CH}$ ), 7.10-7.71 (m, Nap-phH, 18H). ESI MS (m/z): calcd. for 2615.3 obsd. 2639.9([M+Na $\left.]^{+}\right)$. Anal. calcd. for $\mathrm{C}_{113} \mathrm{H}_{135} \mathrm{~N}_{15} \mathrm{O}_{57}: \mathrm{C}, 51.89, \mathrm{H}, 5.20, \mathrm{~N}, 8.03$. found: $\mathrm{C}, 51.21, \mathrm{H}$, $5.01, \mathrm{~N}, 8.22$.

T2b. $0.16 \mathrm{~g}$ from $110.1 \mathrm{~g}\left(45 \%\right.$ in two steps). ${ }^{1} \mathrm{H}$ NMR $\left(400 \mathrm{MHz}, \mathrm{D}_{2} \mathrm{O}\right): 1.49(\mathrm{~d}, 9 \mathrm{H}, J=6.0 \mathrm{~Hz}$, $\left.\mathrm{NapCH}_{3} \times 3\right), 1.71-1.72\left(\mathrm{~m}, 2 \mathrm{H}, \mathrm{COCH}_{2}\right), 2.22-2.24\left(\mathrm{~m}, 2 \mathrm{H}, \mathrm{COCH}_{2}\right), 2.41-2.48$ (brs, $6 \mathrm{H}$, $\mathrm{COCH}_{2} \times 3$ ), 2.80-3.04 (brs, $30 \mathrm{H}, \mathrm{Asp}-\mathrm{BCH}_{2}$ ), 3.44-3.51 (brs, $6 \mathrm{H}$, TRIS-OCH $\mathrm{OCH}_{2} \times 3$ ), 3.79-3.84 (brs, $12 \mathrm{H}, \mathrm{NapOCH}_{3} \times 3+\mathrm{NapCOCH} \times 3$ ), 4.09-4.19 (brs, $8 \mathrm{H}$, TRIS- $\left.\mathrm{CH}_{2} \times 3+\mathrm{GlyCH}_{2}\right), 4.76-5.06(\mathrm{~m}$, $15 \mathrm{H}$, Asp- $\alpha \mathrm{CH}$ ), 7.10-7.67 (m, Nap-phH, 18H). ESI MS (m/z): calcd. for 2960.1 obsd. 1481.2([M+2H] $\left.]^{+} / 2\right)$. Anal. calcd. for $\mathrm{C}_{125} \mathrm{H}_{150} \mathrm{~N}_{18} \mathrm{O}_{66}: \mathrm{C}, 50.71, \mathrm{H}, 5.11, \mathrm{~N}, 8.52$. found: $\mathrm{C}, 50.93, \mathrm{H}$, $4.99, \mathrm{~N}, 8.74$.

T2c. $0.24 \mathrm{~g}$ from $110.1 \mathrm{~g}\left(61 \%\right.$ in two steps). ${ }^{1} \mathrm{H}$ NMR $\left(400 \mathrm{MHz}, \mathrm{D}_{2} \mathrm{O}\right): 1.52(\mathrm{~d}, 9 \mathrm{H}, J=6.0 \mathrm{~Hz}$, $\left.\mathrm{NapCH}_{3} \times 3\right), 1.81-1.84\left(\mathrm{~m}, 2 \mathrm{H}, \mathrm{COCH}_{2}\right), 2.32-2.34\left(\mathrm{~m}, 2 \mathrm{H}, \mathrm{COCH}_{2}\right), 2.45-2.51$ (brs, $6 \mathrm{H}$, $\mathrm{COCH}_{2} \times 3$ ), 2.78-2.99 (brs, $36 \mathrm{H}$, Asp- $\beta_{\mathrm{CH}}$ ), 3.41-3.48 (brs, $6 \mathrm{H}$, TRIS- $\mathrm{OCH}_{2} \times 3$ ), 3.81-3.85 (brs, $12 \mathrm{H}, \mathrm{NapOCH}_{3} \times 3+\mathrm{NapCOCH} \times 3$ ), 4.02-4.26 (brs, $8 \mathrm{H}$, TRIS- $\left.\mathrm{CH}_{2} \times 3+\mathrm{GlyCH}_{2}\right), 4.75-4.96(\mathrm{~m}$, $18 \mathrm{H}$, Asp- $\alpha \mathrm{CH}$ ), 7.10-7.67 (m, Nap-phH, 18H). ESI MS (m/z): calcd. for 3305.87 obsd. 3309.1([M+4H] $\left.]^{+}\right)$. Anal. calcd. for $\mathrm{C}_{137} \mathrm{H}_{165} \mathrm{~N}_{21} \mathrm{O}_{75}: \mathrm{C}, 49.77, \mathrm{H}, 5.03, \mathrm{~N}, 8.90$. found: $\mathrm{C}, 49.96, \mathrm{H}$, $4.87, \mathrm{~N}, 9.01$.

\section{Acknowledgement}

This work was supported by the National Natural Science Foundation of China. (No.20472055).

\section{References}

1. Vogtle, F.; Gestermann, S.; Hesse, R.; Schwierz, H.; Windisch, B. Prog. Polym. Sci. 2000, 25, 987.

2. Tomalia, D. A. Prog. Polym. Sci. 2005, 30, 294.

3. Newkome, G. R.; Shreiner, C. D. Polymer 2008, 49, 1.

4. Esfand, R.; Tomalia, D. A. Drug Discov. Today 2001, 6, 427.

5. Boas, U.; Heegaard, P. M. H. Chem. Soc. Rev. 2004, 33, 43.

6. Lee, C. C.; MacKay, J. A.; Frechet, J. M. J.; Szoka, F. C. Nat. Biotechnol. 2005, 23, 1517.

7. Feng, X.; Taton, D.; Ibarboure, E.; Chaikof, E. L.; Gnanou, Y. J. Am. Chem. Soc. 2008, 130, 11662. 
8. Lenoble, J.; Campidelli, S.; Maringa, N.; Donnio, B.; Guillon, D.; Yevlampieva, N.; Deschenaux, R. J. Am. Chem. Soc. 2007, 129, 9941.

9. Saez, I. M.; Goodby, J. W. Chem.- Eur. J. 2003, 9, 4869.

10. Yang, M.; Wang, W.; Lieberwirth, I.; Wegner, G.. J. Am. Chem. Soc. 2009, 131, 6283.

11. Ouyang, L.; Huang, W. C.; He, G.; Guo, L. Lett. Org. Chem. 2009, 6, 272.

12. Ouyang, L.; Pan, J. Z.; Zhang, Y.; Guo, L. Synthetic Commun. 2009, 39, 4039.

13. Takahashi, T.; Yokogawa, K.; Sakura, N.; Nomura, M.; Kobayashi, S.; Miyamoto, K. Pharm. Res. 2008, 25, 2881.

14. Ishizaki, J.; Waki, Y.; Takahashi-Nishioka, T.; Yokogawa, K.; Miyamoto, K. J. Bone Miner. Metab. 2009, 27, 1.

15. Wang, D.; Miller, S. C.; Kopeckova, P.; Kopecek, J. Adv. Drug Deliv. Rev. 2005, 57, 1049.

16. Hirabayashi, H.; Takahashi, T.; Fujisaki, J.; Masunaga, T.; Sato, S.; Hiroi, J.; Tokunaga, Y.; Kimura, S.; Hata, T. J. Control. Release 2001, 70, 183.

17. Erez, R.; Segal, E.; Miller, K.; Satchi-Fainaro, R.; Shabat, D. Bioorg. Med. Chem. 2009, 17, 4327.

18. Tuuttila, T.; Lipsonen, J.; Lahtinen, M.; Huuskonen, J.; Rissanen, K. Tetrahedron 2008, 64, 10590.

19. Gillies E. R.; Frechet J. M. J. J. Am. Chem. Soc. 2002, 124, 14137.

20. Gillies E. R.; Dy E.; Frechet J. M. J.; Szoka F. C. Mol. Pharmaceut. 2005, 2, 129.

21. Fox M.E.; Guillaudeu S.; Frechet J.M.J.; Jerger K.; Macaraeg N.; Szoka F.C. Mol. Pharmaceut. 2009, 6, 1562.

22. Qandil A.; Al-Nabulsi S.; Al-Taani B.; Tashtoush B. Drug Dev. Ind. Pharm. 2008, 34, 1054.

23. Choi, H. K.; Chun M. K.; Lee S. H.; Jang M. H.; Kim H. D.; Jung C. S.; Oh S. Y. Int. J. Pharm. 2007, 341, 50 . 